\title{
Properties of zirconia-containing glass-ionomer cement
}

\section{(Propriedades de cimento de ionômero de vidro contendo zircônia)}

\author{
T. M. T. C. Melo ${ }^{1}$, I. R. de Oliveiral ${ }^{1 *}$, A. S. Brandim ${ }^{2}$, L. E. S. Soares ${ }^{1}$ \\ ${ }^{I}$ University of Vale do Paraíba, Institute for Research and Development, Av. Shishima Hifumi 2911, \\ S. José dos Campos, SP, Brazil \\ ${ }^{2}$ Instituto Federal de Educação, Ciência e Tecnologia do Piauí, Teresina, PI, Brazil
}

\begin{abstract}
Glass-ionomer cements (GICs) are used as restorative dental materials due to their capacity to chemically adhere to enamel and dentin, low thermal expansion coefficient, and compatibility with dental structures. However, these materials have low resistance to wear and fracture. In this work, zirconia-reinforced GICs were prepared to evaluate the influence of particle size as well as $\mathrm{ZrO}_{2}$ content on their properties. All evaluated composites presented compressive strength values above the pure GIC strength. The highest compressive strength values were obtained with the addition of $8.5 \mathrm{wt} \% \mathrm{ZrO}_{2}$. The average roughness obtained was not significantly changed compared to commercial GIC and the lowest value was for the composite with $10 \mathrm{wt} \% \mathrm{ZrO}_{2}(50 \mathrm{mesh})$. In the microhardness test, the highest values were obtained with the addition of $8.5 \mathrm{wt} \%$ of $\mathrm{ZrO}$. Therefore, the results indicated that the addition of $\mathrm{ZrO}_{2}$ to GIC is an effective alternative to improve the quality of dental restorations.
\end{abstract}

Keywords: glass ionomer, zirconia, compressive strength, roughness, microhardness.

\section{Resumo}

Cimentos de ionômero de vidro (CIVs) são utilizados como materiais restauradores dentários devido à sua capacidade de aderir quimicamente ao esmalte e à dentina, baixo coeficiente de expansão térmica e compatibilidade com estruturas dentárias. No entanto, esses materiais têm baixa resistência ao desgaste e fraturas. Neste trabalho, CIVs reforçados com $\mathrm{ZrO}$, foram preparados para avaliar a influência do tamanho de partícula e do teor de $\mathrm{ZrO}_{2}$ em suas propriedades. Os maiores valores de resistência à compressão foram obtidos com a adição de $8,5 \%$ de $\mathrm{ZrO}_{2}$. A rugosidade média obtida não foi significativamente alterada em comparação com o CIV comercial e o valor mais baixo foi obtido para o compósito com $10 \%$ de $\mathrm{ZrO}_{2}$ (50 mesh). No teste de microdureza, os maiores valores foram obtidos com a adição de 8,5\% de $\mathrm{ZrO}_{2}$. Portanto, os resultados indicaram que a adição de $\mathrm{ZrO}_{2}$ ao CIV é uma alternativa eficaz para melhorar a qualidade das restaurações dentárias.

Palavras-chave: ionômero de vidro, zircônia, resistência à compressão, rugosidade, microdureza .

\section{INTRODUCTION}

The function of a restorative material in dentistry is to replace the biological, functional, and aesthetic harmony of lost dental structures [1]. When applied in posterior restorations, it must possess properties that transmit or resist the applied stresses, which involves the chemical and mechanical forces that often occur in mastication [2]. Compressive strength, roughness, and microhardness stand out among these properties. The compressive strength determines if the material withstands specific stresses [3]. The roughness evaluates the aesthetic appearance, wear, and longevity of restorations [4], while the material's microhardness measures its resistance to permanent deformation. Thus, improvements in these properties lead to better performance of restorative materials during clinical applications [5].

Glass-ionomer cements (GICs) have important properties

*ivonero@univap.br

(D) https://orcid.org/0000-0002-9747-7651 for applications as restorative materials, such as the ability to chemically adhere to the enamel and dentin, low thermal expansion coefficient, and biocompatibility [6-8]. On the other hand, these materials show disadvantages like low wear and fracture resistance, making them unsuitable for applications in posterior-tooth restorations [9-11]. Another limitation of GIC includes high microleakage in sandwich restorations where phosphoric acid etching of GIC prior to the placement of composite resin does not improve the sealing ability of sandwich restorations [12]. GIC materials also are sensitive to initial desiccation and moisture [13] and limited fluoride release in mature cements after fluoride application [14]. This limitation occurs because the topical application of fluoride is capable of recharging GIC but the subsequent high fluoride release only lasts for one or a few days [14]. For this reason, for clinical applications in posterior teeth, GIC is combined with different materials in order to improve their properties of surface wear and fracture resistance. Therefore, GIC-based composites have been developed by adding metal powders [15], hydroxyapatite (HA) powders [16], zirconium dioxide/zirconia $\left(\mathrm{ZrO}_{2}\right)$ 
[17], proline [18], bioactive glass [8], and nanoparticles of titanium dioxide [19] and montmorillonite clay [8, 20, 21]. Despite some advantages of adding some of these materials, the aesthetics were deficient with metallic and HA-silica powders [15, 22]. Proline-containing GIC samples showed significantly higher water sorption values than the control group and a relevant physical property such as wear was not evaluated [15].

To overcome the strength drawbacks of above materials a high strength restorative material reinforced with ceramic and zirconia fillers (zirconia-reinforced GIC) has been recently applied in dentistry [23, 24]. Zirconia-reinforced GIC restorations used in stress-bearing areas showed high strength compared to conventional and silver-reinforced GICs with the added advantage of esthetics [24]. Furthermore, zirconia does not dissolve with increasing soaking time [13] due to its adequate chemical and dimensional stability (high bending strength $400-1000 \mathrm{MPa}$ ) $[17,25]$. The interest in zirconia as a reinforcement material in dentistry [17] is due to its properties and wide applications as a biomaterial [26], particularly its use in dental restorations, fixed partial dental prosthesis structures, and dental implants [27]. This material has mechanical resistance, toughness, and biocompatibility as well as adequate aesthetics, since its color is similar to tooth color [16]. Zirconia is a superior additive for enhancing the mechanical properties and can improve the aesthetic properties by reducing the opaqueness of the conventional GIC or modified material $[15,22,28]$.

A previous study using zirconia-reinforced GIC showed that the size of $\mathrm{ZrO}_{2}$ particles influences the cement properties. The use of nano-sized particles $(5-15 \mathrm{~nm})$ to reinforce a GIC material resulted in low values of mechanical properties compared to the micro-sized particles $(2-10 \mu \mathrm{m})$ because of the low packing density of the nano-sized powders and hence low powder/liquid ratio of GIC [17]. This is a relevant issue regarding GIC and modified GIC materials since the size and distribution of the powder particles [29], storage, and aging also influence the cement resistance [30,31]. The optimization of particle size and distribution is an important factor for the clinical application of GIC since it can produce materials with improved clinical manipulation characteristics and greater resistance, thus prolonging the longevity of the restoration [32]. In this context, the purpose of this work was to determine the influence of $\mathrm{ZrO}_{2}$ particle size as well as the $\mathrm{ZrO}_{2}$ content on zirconia-reinforced GIC properties (compressive strength, roughness, and microhardness). The initial hypothesis is that significant differences in the properties of the zirconia-reinforced GIC would be observed as a function of $\mathrm{ZrO}_{2}$ characteristics.

\section{MATERIALS AND METHODS}

Characterization of GIC and $\mathrm{ZrO}_{2}$ particles: the materials used were glass-ionomer cement (GIC Fuji IX, GC Gold Label, Japan) and zirconia (Prettau Zirconia, Zirkonzahn, Germany). The $\mathrm{ZrO}_{2}$ powder was fragmented with a low-rotation drill fitted with tungsten carbide bits
Table I - Experimental groups to characterize the influence of $\mathrm{ZrO}_{2}$ addition on GIC- $\mathrm{ZrO}_{2}$ composite properties.

[Tabela I - Grupos experimentais para caracterizar a influência da adição de $\mathrm{ZrO}_{2}$ nas propriedades do compósito $\left.\left.\mathrm{CIV}-\mathrm{ZrO}_{2}\right)\right]$.

\begin{tabular}{|c|c|c|}
\hline Group & Composition (wt\%) & \\
\hline \multirow{5}{*}{ GIC } & Fluoro-alumino silicate glass ${ }^{1}$ & 95 \\
\hline & Acrylic acid powder ${ }^{1}$ & 5 \\
\hline & Distilled water ${ }^{2}$ & 50 \\
\hline & Polyacrylic acid ${ }^{2}$ & 40 \\
\hline & Polybase carboxylic acid ${ }^{2}$ & 10 \\
\hline $\mathrm{GICZrO}_{2} 7 \% 45$ mesh & \multirow{3}{*}{$\begin{array}{l}\mathrm{GIC} \\
\mathrm{ZrO}_{2}\end{array}$} & \multirow{3}{*}{$\begin{array}{r}93.0 \\
7.0\end{array}$} \\
\hline GICZrO $7 \% 50$ mesh & & \\
\hline $\mathrm{GICZrO}_{2} 7 \% 80$ mesh & & \\
\hline $\mathrm{GICZrO}_{2} 8.5 \% 45$ mesh & \multirow{3}{*}{$\begin{array}{l}\mathrm{GIC} \\
\mathrm{ZrO}_{2}\end{array}$} & \multirow{3}{*}{$\begin{array}{r}91.5 \\
8.5\end{array}$} \\
\hline $\mathrm{GICZrO}_{2} 8.5 \% 50 \mathrm{mesh}$ & & \\
\hline $\mathrm{GICZrO}_{2} 8.5 \% 80$ mesh & & \\
\hline $\mathrm{GICZrO}_{2} 10 \% 45$ mesh & \multirow{3}{*}{$\begin{array}{l}\text { GIC } \\
\mathrm{ZrO}_{2}\end{array}$} & \multirow{3}{*}{$\begin{array}{l}90.0 \\
10.0\end{array}$} \\
\hline $\mathrm{GICZrO}_{2} 10 \% 50$ mesh & & \\
\hline $\mathrm{GICZrO}_{2} 10 \% 80$ mesh & & \\
\hline
\end{tabular}

(Labordental, Brazil). The next step was grinding in a porcelain jar with porcelain balls using a ball mill (SL-34, Solab, Brazil) with continuous rotation for $1 \mathrm{~h}$ at $150 \mathrm{rpm}$. Then, the resulting powder was sieved and the fractions retained on 45, 50, and 80 mesh sieves were selected. The 80 mesh passing fraction was discarded. These materials were characterized with regard to particle morphology using scanning electron microscopy (SEM, EVO MA10, Zeiss, Germany), crystalline phases using X-ray diffraction (XRD6000 , Shimadzu, Japan) with $\mathrm{CuK} \alpha$ radiation $(\lambda=1.54439$ $\AA$ ), and particle size distribution using a particle size analyzer (S3550, Microtrac, USA), after the ultrasonication of sample suspensions for 15 min (Vibra-cell VCX 500, Sonics, USA).

Preparation of $\mathrm{ZrO}_{2}$-reinforced GIC: the composites were prepared by adding the $\mathrm{ZrO}_{2}$ powders $(45,50$ and 80 mesh) to GIC powders, with $7,8.5$, and $10 \mathrm{wt} \%$ contents. The mixtures were homogenized in a porcelain jar using a ball mill (SL-34, Solab, Brazil) with continuous rotation for $1 \mathrm{~h}$ at $150 \mathrm{rpm}$ (Table I). The samples were prepared by adding powders of commercial cement or GIC- $\mathrm{ZrO}_{2}$ composites to the liquid supplied by the GIC manufacturer, followed by manual mixing on a $10 \mathrm{~mm}$ polished glass plate (Golgram, Brazil) with a plastic spatula (142 Ionomix, Maquira, Brazil) for 15 to $20 \mathrm{~s}$. Then the material was inserted in a stainlesssteel die (internal dimensions: $7 \mathrm{~mm}$ in diameter x 2.5 $\mathrm{mm}$ in thickness), with a Centrix syringe (DFL, Brazil). A vaseline-greased blade (Precision glass line, CRAL, Brazil) was placed on the material in order to prevent bubbles. The GIC and composite samples were analyzed to determine the 
compressive strength, roughness, and microhardness.

Characterization of $\mathrm{ZrO}_{2}$-reinforced GIC: the samples were carefully removed from the dies after $1 \mathrm{~h}$ and placed in a plastic container with distilled water (Quimidrol, Brazil) at $37^{\circ} \mathrm{C}$. The samples were dried after 7 days with absorbent paper (Snack, Melhoramentos Papéis, Brazil) for the compressive strength assay. The compression test was performed using a mechanical testing machine (AG-X, Shimadzu, Japan), according to the ISO 9917-1/2007 standard (Dentistry - water-based cements - part 1). A $1 \mathrm{~mm} / \mathrm{min}$ compression speed, with a $10 \mathrm{kN}$ load cell, was applied along the axes in the vertical position until fracture. Other samples were stored in $1 \mathrm{~L}$ of distilled water (Quimidrol, Brazil) in a plastic container for 7 days [33]. The samples were dried after this period with pressurized air, stored at $33^{\circ} \mathrm{C}$, and polished with silicone points (Microdont, Brazil) in accordance with the manufacturer's instructions. These samples were tested using a precision roughness tester (Talysur PGI Optics, Taylor Hobson, Brazil) to determine the roughness. The mean value for each sample was obtained from five readings for different and equidistant positions at a $1 \mathrm{~mm}$ distance from the sample edge. Three samples were prepared for each group for the microhardness assays. The samples were carefully removed from the dies after $1 \mathrm{~h}$ and sanded with sandpaper disks (SofLex Pop On, 3M, Brazil). The Vickers microhardness analysis followed the ISO 9917-1:2007 standard (Dentistry - waterbased cements - part 1), utilizing a digital microhardness tester (MTC, Shimadzu, Japan), with $10 \mathrm{~N}$ load for $10 \mathrm{~s}$. The mean hardness value was obtained from three indentations in different regions of the samples.

Statistical analysis: the results obtained by the compressive strength, roughness, and microhardness tests were tabulated for descriptive statistical analysis and the means and standard deviation values were determined. For each evaluated property, the data normality was verified using the Shapiro-Wilk test. The next step was the evaluation of the significant differences between variables $\left(\mathrm{ZrO}_{2}\right.$ particle size and content) using the analysis of variance (ANOVA). In the case of significant differences between the variables, the Tukey test for multiple comparisons was applied. All data were tabulated and analyzed using the $\mathrm{R}$ program ( $\mathrm{R}$ Core Team, 2017), considering a 5\% significance level.

\section{RESULTS AND DISCUSSION}

The results for the particle morphology of GIC and $\mathrm{ZrO}_{2}$ obtained by scanning electron microscopy are shown in Fig. 1. It was observed that the ionomer had larger and more irregular particles compared to the $\mathrm{ZrO}_{2}$ particles. These results agreed with those reported in other studies [17, 34, 35]. Additionally, it was observed that the $\mathrm{ZrO}_{2}$ particles appeared as agglomerates, without any significant difference between the different granulometries.

The crystalline phases of the utilized materials were characterized by X-ray diffraction, XRD (Fig. 2). Note that only one peak was identified for the glass ionomer, which coincided with the $\mathrm{SiO}_{2}$ characteristic position, since the

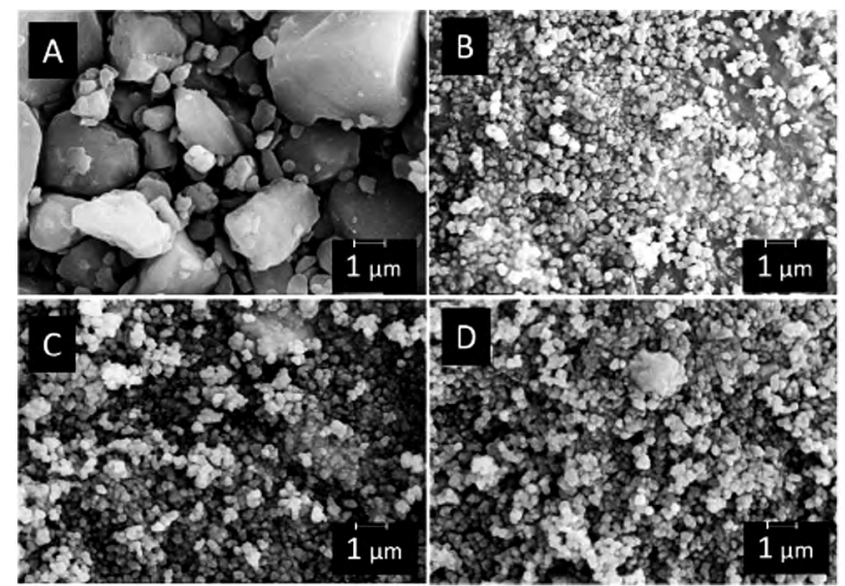

Figure 1: Scanning electron microscopy images of powders: A) conventional glass-ionomer cement; and $\mathrm{ZrO}_{2}$ after grinding and sieving with sieve of: B) 45 mesh; C) 50 mesh; and D) 80 mesh.

[Figura 1: Imagens de microscopia eletrônica de varredura de pós: A) cimento de ionômero de vidro convencional; e $\mathrm{ZrO}_{2}$ após a moagem e peneiramento com peneiras de malha: B) 45; C) 50; e D) 80.]

main component of this material is silicate $(95 \%)$. The other constituents were polymeric materials which do not present peaks in an XRD pattern but appear as wide bands due to their amorphous structure. Other studies also showed that $\mathrm{SiO}_{2}$ is the major component of this material [36-40]. On the other hand, $\mathrm{ZrO}_{2}$ presented a crystalline structure, with characteristic peaks in the XRD pattern (Fig. 2). The results only disclosed the presence of $\mathrm{ZrO}_{2}$ and $\mathrm{Zr}_{0.82} \mathrm{Y}_{0.18} \mathrm{O}_{1.91}$ phases, indicating that the powder was not contaminated during the grinding or sieving processes. The $\mathrm{Zr}_{0.82} \mathrm{Y}_{0.18} \mathrm{O}_{1.91}$ phase existed due to the presence of $4-6 \% \mathrm{Y}_{2} \mathrm{O}_{3}$ in the material, according to the manufacturer's information, in agreement with the literature [17, 41-45].

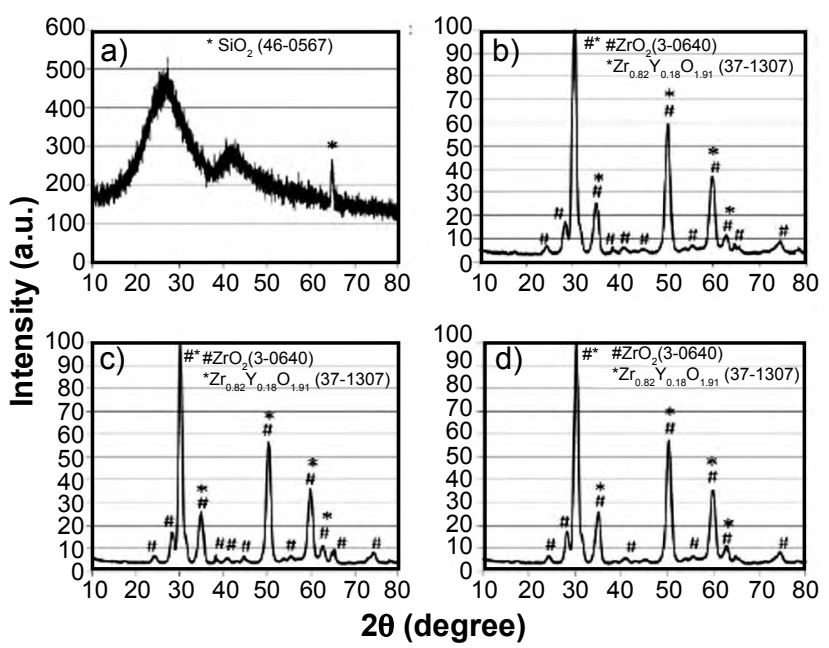

Figure 2: XRD patterns for powders: A) conventional glassionomer cement; and $\mathrm{ZrO}_{2}$ after grinding and sieving with the sieve of: B) 45 mesh; C) 50 mesh; and D) 80 mesh.

[Figura 2: Difratogramas de raios $X$ para os pós: A) cimento de ionômero de vidro convencional; $e \mathrm{ZrO}_{2}$ após moagem $e$ peneiramento com peneiras de malha: B) 45; C) 50; e D) 80.] 
The particle size distributions of the utilized materials were determined (Fig. 3). Note that GIC had particles with an average diameter of 8-9 $\mu \mathrm{m}$ and irregular and amorphous structures (Figs. 1 and 2). These results were similar to those described in the literature $[17,22,46]$. According to the literature, the GIC properties could be optimized by modifying the particle size and the glassionomer composition and that the addition of particles $(>5 \mu \mathrm{m})$ considerably improved its mechanical properties $[21,46,47]$. After grinding and sieving the $\mathrm{ZrO}_{2}$ powders using different sieves, their particle size distribution did not show significant differences, corroborating previous results $[16,17]$. In another study, it was reported that the apparent particle size was larger due to particle sintering, which leads to the formation of agglomerates [47].
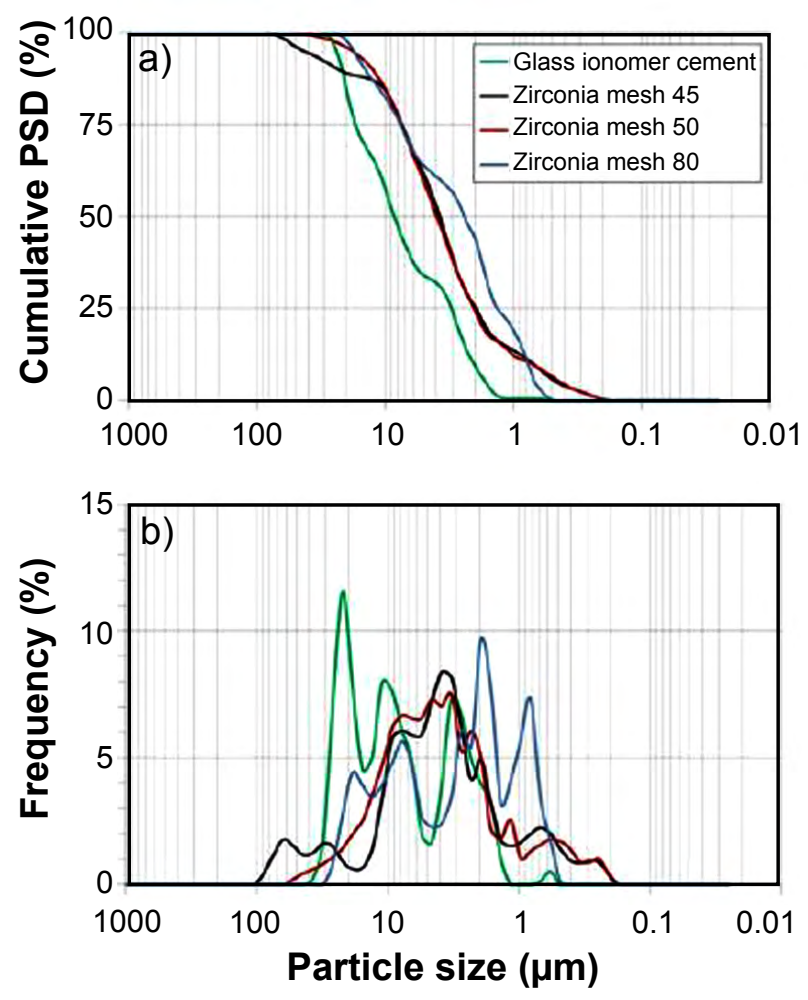

Figure 3: Particle size distribution curves for conventional glassionomer cement and $\mathrm{ZrO}_{2}$ powders, after grinding and sieving with 45, 50, and 80 mesh sieves.

[Figura 3: Curvas de distribuição de tamanho de partículas para o cimento de ionômero de vidro convencional e pós de $\mathrm{ZrO}_{2}$, após moagem e peneiramento com peneiras de malha 45, 50 e 80.]

The morphology results for pure GIC and GIC- $\mathrm{ZrO}_{2}$ composites $\left(7,8.5\right.$, and $10 \mathrm{wt} \%$ of 50 mesh $\mathrm{ZrO}_{2}$ ) samples obtained by scanning electron microscopy are shown in Fig. 4. The addition of $\mathrm{ZrO}_{2}$ to the GIC did not significantly change the surface appearance, in agreement with the literature [48-50].

The compressive strength results for pure GIC cement sample and GIC- $\mathrm{ZrO}_{2}$ composites, containing different amounts of $\mathrm{ZrO}_{2}(7,8.5$ or $10 \mathrm{wt} \%)$, after milling and

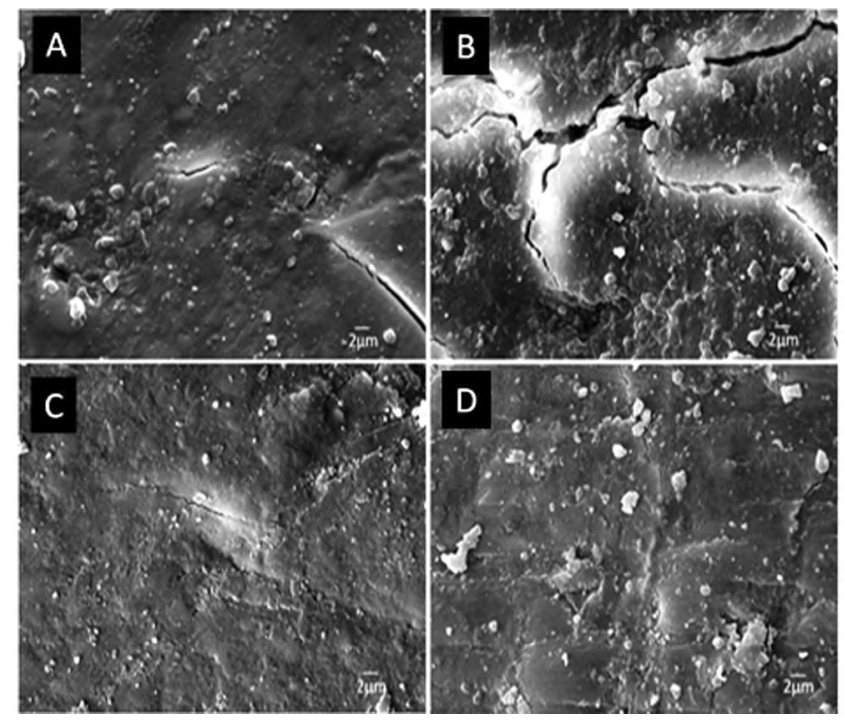

Figure 4: Scanning electron microscopy images of samples: A) pure conventional glass-ionomer cement; B) GIC-7 wt $\% \mathrm{ZrO}_{2}$; C) GIC-8.5 wt $\% \mathrm{ZrO}_{2}$; and D) GIC-10 wt $\% \mathrm{ZrO}_{2}$, using 50 mesh $\mathrm{ZrO}_{2}$ powder.

[Figura 4: Imagens de microscopia eletrônica de varredura de amostras: A) cimento de ionômero de vidro convencional puro; $B$ ) $\mathrm{CIV}-7 \%$ em massa de $\mathrm{ZrO}_{2}$; C) $\mathrm{CIV}-8,5 \%$ em massa de $\mathrm{ZrO}{ }_{2}$; e D) CIV-10\% em massa de $\mathrm{ZrO}$, utilizando pó de $\mathrm{ZrO}_{2}$ de malha 50.]

sieving with 45, 50, and 80 mesh sieves, are shown in Fig. 5a. It is possible to notice that for all evaluated composites, the obtained strength was above the strength of pure GIC, proving the positive effect of $\mathrm{ZrO}_{2}$ addition on the strength of this material. The highest values were obtained for the samples containing $8.5 \mathrm{wt} \%$ of $\mathrm{ZrO}_{2}$, regardless of the granulometry, showing that this is the best content among those evaluated for the optimization of mechanical strength; this is due to the homogeneous incorporation of micronized $\mathrm{ZrO}_{2}$ particles in the glass-ionomer. A compressive strength test is a tool used by physicians and researchers to anticipate the performance of new restorative materials due to the need for material with better resistance properties to withstand the stress of masticatory forces. In fact, charging GIC with $\mathrm{ZrO}_{2}$ improves the material mechanical properties, enhancing restoration structural integrity in load bearing areas due to the strong bonds established among ceramic glass matrix and $\mathrm{ZrO}_{2}$ particles [24, 29, 51-53]. Moreover, zirconia has transformational toughening property, which stops the growth of cracks, and confers strong mechanical properties to the composites $[24,54]$ as could be observed in our results. It was also observed that compressive strength did not vary significantly with different sieving $(45,50$ or 80 mesh). However, this result was expected since electron microscopy analysis showed that particles of similar size were obtained regardless of using 45,50 or 80 mesh sieves.

The roughness results for pure GIC sample and GIC$\mathrm{ZrO}_{2}$ composites are shown in Fig. 5b. It can be seen that the obtained average roughness was not significantly different from the commercial GIC roughness value for most treatments. Only the composite $10 \% \mathrm{ZrO}_{2} 50$ mesh 

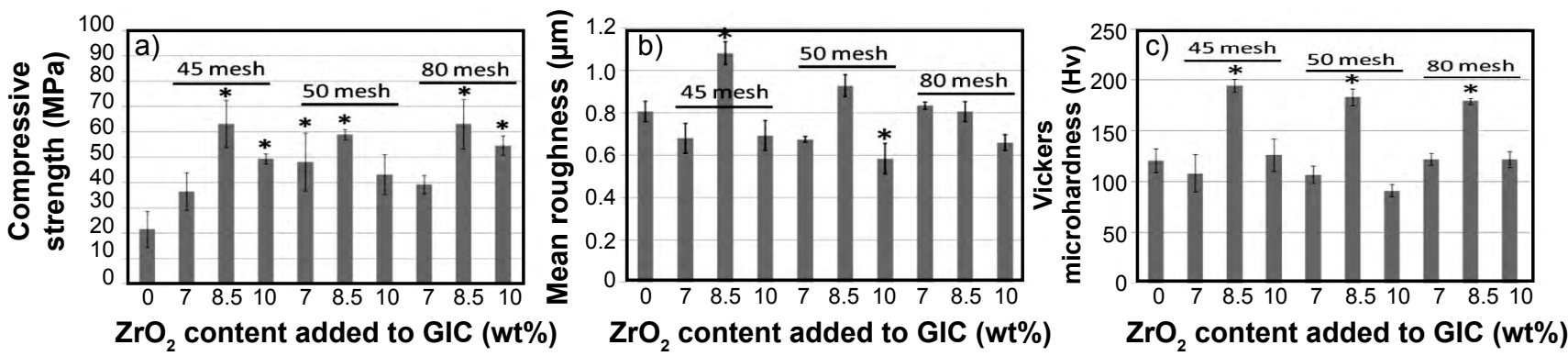

Figure 5: Compressive strength (a), mean roughness (b), and microhardness (c) of pure GIC and $\mathrm{GIC}_{\mathrm{Z}} \mathrm{ZrO}_{2}$ composites, with different $\mathrm{ZrO}_{2}$ contents $(7,8.5$, and $10 \mathrm{wt} \%)$ and granulometry $(45,50$ and $80 \mathrm{mesh})$. The asterisks indicate significant differences in comparison with commercial GIC.

[Figura 5: Resistência à compressão (a), rugosidade média (b) e microdureza (c) de CIV comercial puro e dos compósitos CIV-ZrO ${ }_{2}$, com diferentes teores de $\mathrm{ZrO}_{2}$ (7, 8,5 e 10\% em massa) e granulometria (malha 45, 50 e 80). Os asteriscos indicam diferenças significativas em comparação com o CIV comercial.]

showed significant reduction of the roughness in comparison with the commercial GIC (Fig. 5b), however, it was also observed that this treatment showed no significant variation to commercial GIC in the compression tests, and may not be a viable alternative to be used in posterior restorations. On the other hand, the composite $8.5 \% \mathrm{ZrO}_{2} 45$ mesh was the only one to show a significant increase in roughness. However, this possible disadvantage can be overcome by polishing the composite. The surface roughness of a restoration material has a great influence on aesthetic appearance, wear, and longevity. A rough surface facilitates the accumulation of plaque, surface discoloration, and gingival inflammation [4]. A comparative study of roughness between Zirconomer, Fujii IX Extra GC, and Ketac Molar revealed that the $\mathrm{ZrO}_{2}$ (Zirconomer) composite has higher roughness than the other materials; however, the proportion of $\mathrm{ZrO}_{2}$ and its granulometry were not given. The increased roughness may be due to the large number and the size of filler particles incorporated into the cement, which leads to opacity in the material [4]. The surface roughness of six different GICs was evaluated and noted that the particle size, shape, and distribution, number of particles, interfacial bonding between particles, and interfacial bond between the particles and matrix contributed to the surface finish and polishing. Moreover, the composite roughness increased with the percentage of $\mathrm{ZrO}_{2}$ particles added to GIC [55]. This was noticed after a simulated tooth-brushing test and was caused by the removal of $\mathrm{ZrO}_{2}$ particles from the composite surface, promoting surface excavation. However, the composites investigated in this work did not present a roughness increase due to the addition of $\mathrm{ZrO}_{2}$, probably because we did not carry out a simulated tooth-brushing test before the roughness test.

The microhardness results for commercial GIC and GIC$\mathrm{ZrO}_{2}$ composites are shown in Fig. 5c. It is possible to see that the composites with $8.5 \mathrm{wt} \%$ of $\mathrm{ZrO}_{2}$ had significantly higher values when compared to pure GIC, regardless of their granulometry, as showed in compressive strength tests (Fig. 5a). Other studies also showed that addition of $\mathrm{ZrO}_{2}$ particles to the GIC improves microhardness [51,56], enhances the structural integrity of the restoration and transmits superior mechanical properties for posterior restoration [57, 58]. Our results corroborated these findings, however, we found out that the best proportion of $\mathrm{ZrO}_{2}$ to be used in restorations is $8.5 \%$. Larger or smaller concentrations did not lead to significant differences in relation to the commercial GIC regarding microhardness (Fig. 5c). GIC can be optimized by changing the particle size and composition of the glass [32]. As it was observed in our results, optimization (at 8.5\% $\mathrm{ZrO}_{2}$ ) is important since low concentrations of zirconia did not significantly increase the mechanical properties of the composite, while high concentrations lead to the formation of agglomerates that contribute negatively to its mechanical properties [51]. The superior mechanical properties found in this research is attributed to the inclusion of the correct zirconia charges and the homogeneity of the glass particles, which further increases the durability of the material and its strength to withstand the occlusal load [57].

\section{CONCLUSIONS}

Glass ionomer composites reinforced with $\mathrm{ZrO}_{2}$ particles presented higher compressive strength compared to pure GIC, with highest values found for samples containing 8.5\% of zirconia, regardless of their granulometry. The roughness of the material was not significantly altered in relation to the commercial GIC for most treatments. Adding $\mathrm{ZrO}_{2}$ to GIC increased microhardness when the concentration $8.5 \%$ was used, regardless of its granulometry. The different sieving treatments tested in this work $(45,50$ and 80 mesh) did not influence in strength, microhardness or roughness of the composite.

\section{REFERENCES}

[1] N. Abdulsamee, A.H. Elkhadem, EC Dent. Sci. 15, 4 (2017) 134.

[2] M. Moshaverinia, A. Borzabadi-Farahani, A. Sameni, A. Moshaverinia, S. Ansari, Dent. Mater. J. 35, 5 (2016) 817.

[3] W.D. Callister, Materials science and engineering: an introduction, John Wiley Sons, New York (1994).

[4] S. Asafarial, Dentistry 7, 5 (2017) 1.

[5] S. Farahn, S. Shosle, M. Kowkabi, J. Clin. Exp. Dent. 9, 6 (2017) e805. 
[6] H. Al Zraikat, J.E. Palamara, H.H. Messer, M.F. Burrow, E.C. Reynolds, Dent. Mater. 27, 3 (2011) 235.

[7] J. Zhao, Y. Weng, D. Xie, Dent. Mater. 25, 4 (2009) 526.

[8] M.S. Baig, G.J.P. Fleming, J. Dent. 43 (2015) 897.

[9] J.E. Mckinney, J.M. Antonucci, N.W. Rupp, J. Dent. Res. 67, 5 (1988) 831.

[10] M. Khoroushi, F. Keshani, Dent. Res. J. 10, 4 (2013) 411. [11] N.S. Kabil, A.S. Badran, M. Wassel, Int. J. Paediatr. Dent. 27 (2017) 380.

[12] A.D. Bona, C. Pinzetta, V. Rosa, J. Appl. Oral Sci. 15, 3 (2007) 230.

[13] G.J. Mount, Oper. Dent. 24 (1999) 115.

[14] A.M. De Witte, E.A. De Maeyer, R.M. Verbeeck, L.C. Martens, Biomaterials 21, 5 (2000) 475.

[15] Y.W. Gu, A.U.J. Yap, P. Cheang, Y.L. Koh, K.A. Khor, J. Non-Cryst. Solids 351, 6-7 (2005) 508.

[16] Y.W. Gu, A.U.J. Yap, P. Cheang, K.A. Khor, Biomaterials 26, 7 (2005) 713.

[17] Y.W. Gu, A.U.J. Yap, P. Cheang, K.A. Khor, Scripta Mater. 52, 2 (2005) 113.

[18] S. Ansari, M. Moshaverinia, N. Roohpour, W.W. Chee, S.R. Schricker, A. Moshaverinia, J. Prosthet. Dent. 110, 5 (2013) 408 .

[19] E.E. Shaymaa, I.M. Hamouda, M.V. Swain, J. Dent. 39, 9 (2011) 589.

[20] A.H. Dowling, A. Stamboulis, G.J. Fleming, J. Dent. 34, 10 (2006) 802.

[21] S. Najeeb, Z. Khurshid, M.S. Zafar, A.S. Khan, S. Zohaib, J.M. Martí, S. Sauro, J.P. Matinlinna, I.U. Rehman, Int. J. Mol. Sci. 17, 7 (2016) 1134.

[22] I.A. Rahman, S.M. Masudi, N. Luddin, R.A. Sheikh, Bull. Mater. Sci. 37 (2014) 213.

[23] V.P. Chalissery. J. Contemp. Dent. Pract. 17, 5 (2016) 394. [24] H.P. Bhatia, S. Singh, S. Sood, N. Sharma, Int. J. Clin. Pediatr. Dent. 10, 1 (2017) 49.

[25] T. Kasuga, M. Yoshida, A.J. Ikushima, J. Mater. Sci. Mater. Med. 4, 1(1993) 36.

[26] M. Uo, G. Sjögren, A. Sundh, F. Watari, M. Bergman, U. Lerner, Dent. Mater. 19, 6 (2003) 487.

[27] Y. Kawai, M. Uo, Y. Wang, S. Kono, S. Ohnuki, F. Watari, Dent. Mater. J. 30, 3 (2011) 286.

[28] I.A. Rahman, N.A.M. Ghazali, W.Z.W. Bakar, S.M. Masudi, Ceram. Int. 43, 16 (2017) 13247.

[29] A. Moshaverinia, N. Roohpour, W.W.L. Chee, S.R. Schricker, J. Mater. Chem. 21, 5 (2011) 1319.

[30] Y.W. Gu, A.U.J. Yap, P. Cheang, R. Kumar, Biomaterials 25, 18 (2004) 4029.

[31] Y. Wang, B.W. Darvell, Dent. Mater. 25, 8 (2009) 952.

[32] L.H. Prentice, M.J. Tyas, M.F. Burrow, Dent. Mater. 21, 6 (2005) 505.

[33] I.M. Hamouda, J. Esthet. Restor. Dent. 23, 5 (2011) 315. [34] A. Nevarez-Rascon, S. González-Lopez, L.S. AcostaTorres, M.M. Nevarez-Rascon, E. Orrantia-Borunda, Dent. Mater. J. 35, 3 (2016) 392.

[35] J.C.M. Souza, J.B. Silva, A. Aladim, O. Carvalho, R.M. Nascimento, F.S. Silva, A.E. Martinelli, B. Henriques, Open
Dent. J. 10 (2016) 58.

[36] H.E. Sennou, A.A. Lebugle, G.L. Gregoire, Dent. Mater. 15, 4 (1999) 229.

[37] S. Banijamali, B.E. Yekta, H.R. Rezaie, V.K. Marghussian, Thermochim. Acta 488, 1-2 (2009) 60.

[38] N. Zainuddin, N. Karpukhina, R.V. Law, R.G. Hill, Dent. Mater. 28, 10 (2012) 1051.

[39] B. Dickey, R. Price, D. Boyd, J. Biomater. Appl. 31, 5 (2016) 730.

[40] D.D. Cibim, M.T. Saito, P.A. Giovani, A.F.S. Borges, V.G.A. Pecorari, O. PonceGomes, P.N. Lisboa-Filho, F.H. Nociti-Junior, R.M. Puppin-Rontani, K.R. Kantovitz, Int. J. Biomater. 2017, 6 (2017) 1.

[41] R. Srinivasan, C.R. Hubbard, O.B. Cavin, B.H. Davis, Chem. Mater. 5, 1 (1993) 27.

[42] J. Perdigão, A.M. Pinto, R.C. Monteiro, F.M. Braz Fernandes, P. Laranjeira, J.P. Veiga, Dent. Mater. J. 31, 2 (2012) 256.

[43] F. Egilmez, G. Ergun, I. Cekic-Nagas, P.K. Vallittu, L.V. Lassila, J. Mech. Behav. Biomed. Mater. 37 (2014) 78.

[44] D.V. Andreev, E.E. Sergeev, A.G. Gribovskii, L.L. Makarshin, S.A. Prikhod'ko, N.Y. Adonin, Z.P. Pai, V.N. Parmon, Chem. Eng. J. 330 (2017) 899.

[45] W. Li, X. Nie, X. Jiang, A. Zhang, F. Ding, M. Liu, Z. Liu, X. Guo, C. Song, Appl. Catal. B 220 (2018) 397.

[46] T. De Caluwé, C.W. Vercruysse, S. Fraeyman, R.M. Verbeeck, Dent. Mater. 30, 9 (2014) 1029.

[47] A. Opalinska, I. Malka, W. Dzwolak, T. Chudoba, A. Presz, W. Lojkowski, Beilstein J. Nanotechnol. 6 (2015) 27.

[48] A. Moshaverinia, S. Ansari, M. Moshaverinia, N. Roohpour, J.A. Darr, I. Rehman, Acta Biomater. 4, 2 (2008) 432.

[49] S. Goenka, R. Balu, T.S.S. Kumar, J. Mech. Behav. Biomed. Mater. 7 (2012) 69.

[50] M. Khaghani, A. Doostmohammadi, S. Alizadeh, Austin J. Biotechnol. Bioeng. 3, 3 (2016) 1068.

[51] R.L.P. Santos, M. Buciumeanu, F.S. Silva, J.C.M. Souza, R.M. Nascimento, F.V. Motta, B. Henriques, Tribol. Int. 103 (2016) 379.

[52] H.A. Abo-Mosallam, D. Kim, H. Kim, H. Lee, Ceram. Int. 42, 4 (2016) 5107.

[53] S. Tiwari, M. Kenchappa, D. Bhayya, S. Gupta, S. Saxena, S. Satyarth, A. Singh, M. Gupta, J. Clin. Diagn. Res. 10, 4 (2016) 90.

[54] H.C. Li, D.G. Wang, X.G. Meng, C.Z. Chen, Colloids Surf. B 118, 1 (2014) 226.

[55] O. Bala, H.D. Arisu, I. Yikilgan, S. Arslan, A. Gullu, Eur. J. Dent. 6, 1 (2012) 79.

[56] S. Mohanty, S. Ramesh, J. Adv. Pharm. Educ. Res. 7, 3 (2017) 291.

[57] C.M. Shetty, V. Sadananda, M.N. Hegde, A. Lagisetti, A. Shetty, T. Mathew, S. Shetty, Sch. J. Dent. Sci. 4, 6 (2017) 259.

[58] I. Abrahman, N.A.M. Ghazali, W.Z.W. Bakar, S.M. Masudi, Ceram. Int. 43, 16 (2017) 13247.

(Rec.04/11/2018, Rev. 13/01/2019, Ac. 20/02/2019) 